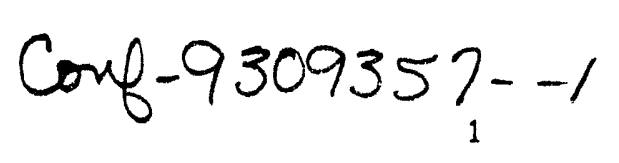

$\mathrm{BNL}-60066$

\title{
DETERMINATION OF RADIOBIOLOGICAL PARAMETERS FOR THE SAFE CLINICAL APPLICATION OF BNCT
}

\author{
J.W. Hopewell' ${ }^{1}$ G.M. Morris ${ }^{1}$ and J.A. Coderre ${ }^{2}$ \\ ${ }^{2}$ Research Institute (University of Oxford), Churchill Hospital, Oxford, OX3 7LJ, \\ U.K. and ${ }^{2}$ Medical Department, Brookhaven National Laboratory, Upton, \\ New York 11973, U.S.A.
}

\section{INTRODUCTION}

The encouraging, but still inconclusive, results presented by Hatanaka et al. (1992) for the treatment of brain tumours, are a factor that has led the renewed international interest in BNCT. This has involved the development of more penetrating, reactor derived, epithermal neutron beams (Moss et al., 1992). In addition, there has been a gradual accumulation of pharmacokinetic data for potentially suitable boron $\left[{ }^{10} \mathrm{~B}\right]$ capture agents such as $\mathrm{Na}_{2} \mathrm{~B}_{12} \mathrm{H}_{11} \mathrm{SH}$ [BSH] (Frankhauser et al., 1992) and the development of criteria for the use of boronophenylaline [BPA] in brain tumour patients. This suggests that clinical studies with BNCT may be initiated both in Europe and North America within the next few years. However, prior to such clinical trials taking place it is important that data on radiobiological parameters are obtained. This specifically applies to normal tissues, since in the 1950s concern about adverse morbidity led to the abandoning of treatments for high-grade gliomas in the United States (Slatkin, 1991).

In the present report the effects of BNCT irradiation on the skin and spinal cord of Fischer 344 rats, for known concentrations of ${ }^{10} \mathrm{~B}$ in the blood and these normal tissues, are compared with the effects of the neutron beam alone or photon irradiation. The biological effectiveness of irradiation in the presence of the capture agents BSH and BPA have been compared. Irradiations were carried out using the thermal beam of the Brookhaven Medical Research Reactor (BMRR). Therapy experiments were also carried out as part of this study, using the rat 9L-gliosarcoma cell line, in order to establish the potential therapeutic advantage that might be achieved using the above capture agents. This cell line grows as a solid tumour 'in vivo' as well as 'in vitro' (Coderre et al., 1993). The implications of these findings, with respect to the clinical use of the Petten HBII based epithermal neutron beam, will be discussed.

\section{BORON CAPTURE AGENTS AND THEIR BIODISTRIBUTION}

The ideal ${ }^{10} \mathrm{~B}$-compound for therapy should accumulate selectively in tumours, relative to blood/normal tissues [i.e. a significant tumour:blood/normal tissue ratio]. The microdistribution of the capture agent should also be such that it leads to a greater effective energy deposition in tumour clonogens, as compared with the target cell populations in normal tissues [i.e. the compound biological effectiveness factor (CBEfactor) should be higher for tumours than for normal tissues]. It should also be realised that when neutron beams are significantly contaminated with fast neutrons and/or $\gamma$ rays, a feature of reactor derived beams and specifically epithermal beams, then the ${ }^{10} \mathrm{~B}$ concentration in the blood/normal tissue should be as high as is reasonabiy possible in 
order to maximise the contribution of the dose from the ${ }^{10} \mathrm{~B}(\mathrm{n}, \alpha)^{7} \mathrm{Li}$ reaction to reach normal tissue tolerance. This will enhance the significance of the above factors and maximise the therapeutic ratio. These factors were taken into account when designing the present animal studies.

In the studies of normal tissue toxicity, BSH was given as a single i.v. infusion at $100 \mathrm{mg} / \mathrm{kg}$ body weight over $10 \mathrm{~min}$. Local irradiation of a $15 \mathrm{~mm}$ length of the cervical spinal cord and overlying skin was carried out, using a $15 \mathrm{~mm}$ diameter collimator, 30 min after the end of the infusion. The ${ }^{10} \mathrm{~B}$ levels in the blood and skin were then $100 \mu \mathrm{g} / \mathrm{g}$, with no measurable amount in the spinal cord. BPA was administered orally as two doses of $750 \mathrm{mg} / \mathrm{kg}$ body weight, $3 \mathrm{hrs}$ apart. Irradiations were carried out $3 \mathrm{hrs}$ after the final oral dose when the ${ }^{10} \mathrm{~B}$ level in skin and spinal cord was $10 \mu \mathrm{g} / \mathrm{g}$, compared with $12 \mu \mathrm{g} / \mathrm{g}$ in the blood.

The proportional contributions to the physical radiation dose from the different components of the beam, at the skin surface and at the depth of the spinal cord $(10 \mathrm{~mm})$, are given in Table 1. Comparable data are given for irradiation in the presence of a capture agent. The contribution of the induced $\alpha$-particles to the total dose to the skin and spinal cord (blood) was $-90 \%$ using BSH, lower with BPA, reflecting the lower absolute concentration of ${ }^{10} \mathrm{~B}$ that was attained using this agent.

Table 1. Dosimetric characteristics for the irradiation of rat skin and spinal cord/blood at $10 \mathrm{~mm}$ depth with the BMRR thermal neutron beam.

Contribution to the physical radiation dose (\%)

\begin{tabular}{|c|c|c|c|c|c|}
\hline Irradiation & Site & $\begin{array}{l}\text { Fast } \\
\text { Neutrons }\end{array}$ & $\gamma$-rays & $N(\mathrm{n}, \mathrm{p})$ & ${ }^{10} \mathrm{~B}(\mathrm{n}, \alpha)^{7} \mathrm{Li}$ \\
\hline Beam only & $\begin{array}{l}\text { A } \\
\text { B }\end{array}$ & $\begin{array}{l}33.7 \\
35.1\end{array}$ & $\begin{array}{l}39.6 \\
50.9\end{array}$ & $\begin{array}{l}26.7 \\
14.0\end{array}$ & - \\
\hline Beam + BSH & $\begin{array}{l}\text { A } \\
\text { B }\end{array}$ & $\begin{array}{l}3.2 \\
5.9\end{array}$ & $\begin{array}{l}3.8 \\
8.6\end{array}$ & $\begin{array}{l}2.6 \\
2.4\end{array}$ & $\begin{array}{l}90.4 \\
83.1^{\mathrm{a}}\end{array}$ \\
\hline Beam + BPA & $\begin{array}{l}\text { A } \\
\text { B }\end{array}$ & $\begin{array}{l}17.4 \\
22.0\end{array}$ & $\begin{array}{l}20.4 \\
31.9\end{array}$ & $\begin{array}{c}13.8 \\
8.8\end{array}$ & $\begin{array}{l}48.4 \\
37.3^{b}\end{array}$ \\
\hline
\end{tabular}

A skin surface : B $10 \mathrm{~mm}$ depth (spinal cord)

blood dose, $100 \mu \mathrm{g} / \mathrm{g}^{10} \mathrm{~B}$ : ${ }^{b}$ blood/spinal cord dose, $10-12 \mu \mathrm{g} / \mathrm{g}{ }^{10} \mathrm{~B}$

For the experimental therapy studies with the 9L-gliosarcoma model 'in vivo',the BSH dimer (BSSB) was used in addition to BSH, both were infused i.v. over 3 days at $50 \mu \mathrm{g}$ ${ }^{10} \mathrm{~B} / \mathrm{g}$ body weight and irradiations were carried out shortly after the end of the infusion, as described previously (Joel et al., 1990). BPA was administered as per the normal tissue studies or as a single i.p. injection of BPA-fructose $(1200 \mathrm{mg} \mathrm{BPA} / \mathrm{kg}$ body 
weight). The tumour:blood and tumour:brain ratios obtained are listed in Table 2. A positive tumour:blood ratio was not-achieved for the BSH monomer or dimer (BSSB), although absolute ${ }^{10} \mathrm{~B}$ tumour levels were higher in the case of the dimer, $37 \pm 10 \mu \mathrm{g} / \mathrm{g}$ as compared with $18 \pm 5 \mu \mathrm{g} / \mathrm{g}$ for BSH. Witk BPA tumour:blood ratios were -3.5 and ${ }^{10} \mathrm{~B}$ levels were always similar in blood and brain. The highest ${ }^{10} \mathrm{~B}$ level was achieved with the BPA-fructose mixture i.e. $90 \pm 8 \mu \mathrm{g} / \mathrm{g}$ as compared with $39 \pm 5 \mu \mathrm{g} / \mathrm{g}$ for BPA alone.

Table 2. Tumour (9L-gliosarcoma): blood/normal brain ratios

$\begin{array}{lll}\text { Capture agent } & \text { Tumour:Blood } & \text { Tumour:Brain }\end{array}$

$\begin{array}{lcc}\text { BSH } & 0.71 \pm 0.2 & -8 \\ \text { BSSB } & 0.76 \pm 0.3 & -17 \\ \text { BPA } & 3.3 \pm 0.5 & 3.9 \pm 0.6 \\ \text { BPA-fructose } & 3.2 \pm 0.4 & 5.1 \pm 0.6\end{array}$

\section{NORMAL TISSUE EFFECTS FOLLOWING BNCT IRRADIATION}

Skin on the mid-dorsal line of the neck showed a distinctiy bi-phasic reaction after irradiation with the BMRR thermal beam, with and without the addition of a capture agent. The first phase reaction, moist desquamation, reached a peak at 14 days after irradiation and healing occurred at a rate related to the total exposure dose. The second phase reaction, which involved the necrosis of dermal tissue, was first seen after a latent interval of $\geq 24$ weeks, well after the acute epithelial reaction had healed. Both phases of damage showed a dose-related incidence for the development of these effects. These data were used to obtain dose-effect curves, from which $\mathrm{ED}_{50}( \pm \mathrm{SE})$ values, the doses required to produce the effect in 50\% of skin sites, were obtained. Animals irradiated with X-rays only showed acute moist desquamation, they subsequently developing CNS damage and were killed after lower doses than those required to produce dermal necrosis.

The $\mathrm{ED}_{\mathrm{s}_{0}}( \pm \mathrm{SE})$ values for each reaction, for differing irradiation conditions, expressed in terms of the beam dose, the ${ }^{10} \mathrm{~B}(\mathrm{n}, \alpha)^{7} \mathrm{Li}$ reaction dose and the total dose are shown in Table 3. For both acute and late skin reactions the physical dose from the neutron beam required to produce a given effect was reduced when a capture agent was added. However, for the late skin reactions and the acute reaction associated with the addition of $\mathrm{BSH}$, a very high physical dose from the ${ }^{10} \mathrm{~B}(\mathrm{n}, \alpha)^{7} \mathrm{Li}$ reaction was required to compensate for the reduction in the beam only dose. This calculation assumed a uniform distribution of ${ }^{10} \mathrm{~B}$. This can only be interpreted as a very inefficient killing of cells by the induced $\alpha$-particles, a factor bome out by the low compound biological effectiveness (CBE) factors derived from the data (Table 4). The higher CBE-factor of $3.74 \pm 0.7$ obtained for acute moist desquamation, when the capture agent was BPA, might indicate that the ${ }^{10} \mathrm{~B}$ was being selectively accumulated in epidermal basal cells. 
Table 3. $E D_{s 0}( \pm S E)$ values for normal tissue effects in rats following irradiation from X-rays, BMRR thermal neutron or BNCT exposures.

Irradiation

Contribution to $\mathrm{ED}_{50} \pm \mathrm{SE}$ (Gy) from:Total Dose

Beam

${ }^{10} \mathrm{~B}$-capture

$\mathrm{ED}_{\mathbf{3}} \pm \mathrm{SE}(\mathrm{Gy})$

A) Skin (acute moist desquamation)

$\begin{array}{lccc}\text { Beam + BSH }(100 \mu \mathrm{g} / \mathrm{g}) & 4.56 \pm 0.25 & 47.86 \pm 0.89 & 52.42 \pm 0.83 \\ \text { Beam + BPA }(10 \mu \mathrm{g} / \mathrm{g}) & 5.96 \pm 0.45 & 5.69 \pm 0.92 & 11.65 \pm 0.8 \\ \text { Beam only } & 12.05 \pm 0.45 & - & 12.05 \pm 0.45 \\ \text { X-rays only } & - & - & 42.15 \pm 2.24\end{array}$

B) Skin (late dermal necrosis)

$\begin{array}{lccr}\text { Beam + BSH }(100 \mu \mathrm{g} / \mathrm{g}) & 4.5 \pm 0.67 & 47.5 \pm 1.19 & 52.0 \pm 0.98 \\ \text { Beam + BPA }(10 \mu \mathrm{g} / \mathrm{g}) & 13.48 \pm 1.18 & 12.87 \pm 1.68 & 26.35 \pm 1.19 \\ \text { Beam only } & 16.17 \pm 0.82 & - & 16.17 \pm 0.82 \\ \text { X-rays only } & - & - & (56.6 \pm 2.87)^{(2)}\end{array}$

C) Spinal Cord (CNS)

$\begin{array}{lccc}\text { Beam + BSH }(100 \mu \mathrm{g} / \mathrm{g}) & 5.41 \pm 0.38 & 24.93 \pm 2.68 & 30.34 \pm 2.65 \\ \text { Beam + BPA }(10-12 \mu \mathrm{g} / \mathrm{g}) & 8.88 \pm 0.44 & 4.93 \pm 0.65 & 13.81 \pm 0.49 \\ \text { Beam only } & 13.58 \pm 0.38 & - & 13.58 \pm 0.38 \\ \text { X-rays only } & - & - & 21.5 \pm 0.46\end{array}$

${ }^{2)} \mathrm{ED}_{\mathrm{so}}$ value estimated assay assuming a $\mathrm{RBE}$ for late dermal necrosis of 3.5 , comparable to that for moist desquamation

Table 4. Summary of compound biological effectiveness (CBE) factors for normal tissue effects following BNCT irradiation.

\begin{tabular}{|c|c|c|}
\hline \multirow[b]{2}{*}{ Radiation Reaction } & \multicolumn{2}{|c|}{ CBE-Factor } \\
\hline & BSH & BPA \\
\hline Skin - moist desquamation ${ }^{(\mathrm{a})}$ & $0.56 \pm 0.06$ & $3.74 \pm 0.7$ \\
\hline Skin - dermal necrosis ${ }^{(b)}$ & $0.86 \pm 0.08$ & $0.73 \pm 0.42$ \\
\hline CNS - spinal cord ${ }^{(c)}$ & $0.52 \pm 0.06$ & $1.52 \pm 0.21$ \\
\hline
\end{tabular}

${ }^{(2, b)}$ Based on a RBE for the thermal beam at the skin surface of 3.5

${ }^{(c)}$ Based on an estimated RBE for the thermal beam at the depth of the spinal cord $(10 \mathrm{~mm})$ of 1.58 
Following irradiation of the spinal cord, paralysis developed after a latent interval of 20-24 weeks, irrespective of the type of treatment, although the incidence of the effect was dose-related. Histological observations showed the selective development of white matter necrosis in all treatment groups even those receiving $\mathrm{BSH}$, where the ${ }^{10} \mathrm{~B}$ was restricted to the vascular lumen. This lesion is characteristic of changes induced in human brain after excessive photon irradiation. High doses from the induced $\alpha$-particles were again required to compensate for the reduction in beam dose when BSH is used as the capture agent, as is indicated by the low CBE-factor (Table 4). The higher CBE-factor $(1.52 \pm 0.21)$ for BPA reflects the difference in microdistribution of ${ }^{10} \mathrm{~B}$ in CNS tissues when using this compound.

\section{EXPERIMENTAL THERAPY STUDIES WITH THE 9L-GLIOSARCOMA}

Tumours were irradiated locally 14 days after the implantation of $10^{4}$ cultured cells in $1 \mu \mathrm{l}$ of medium at a depth of $5 \mathrm{~mm}$ beneath the surface of the skull. Cologenic cell survival was assayed 'in vitro' from cells removed from the tumour within $5 \mathrm{~min}$ of irradiation, as described previously (Coderre et al., 1993). These results were compared with 'in vitro' irradiation where the capture agents BPA, BSH and BSSB were added to the cell cultures at a concentration of $-25 \mathrm{mg}{ }^{10} \mathrm{~B} / \mathrm{ml}$ of growth medium.

The results of these studies are summarised in Table 5. The RBE of the beam, based on data for 9L-gliosarcoma cells, was similar for irradiation 'in vivo' and 'in vitro'. For $\mathrm{BSH}$ and BSSB similar CBE-factor values were obtained. However, for irradiation 'in vitro', a much higher $\mathrm{CBE}$-factor was obtained for the same ${ }^{10} \mathrm{~B}$ concentration added to the medium for BPA as compared with BSH/BSSB. This might, as in the epidermis, indicate the ability of these cells to selectively accumulate this capture agent. This trend was repeated for irradiations carried out 'in vivo', although there was an overall reduction in both $\mathrm{CBE}$-factor values. This possibly reflects a more heterogenous distribution of ${ }^{10} \mathrm{~B}$ in solid tumours. The microdistribution of ${ }^{10} \mathrm{~B}$ resulting from the administration of BPA is clearly more advantageous than for BSH in this 'in vivo' rat tumour model.

Table 5. RBE and CBE-factors, relative to $250 \mathrm{kV} \mathrm{X}$-rays, based on a surviving fraction of 0.01 for 9L-gliosarcoma cells irradiated 'in vitro' or 'in vivo' (assayed 'in vitro')

Irradiation 'in vitro(a) 'in vivo' ${ }^{(\mathrm{b})}$

\begin{tabular}{llr}
\hline Beam only & 2.6 & 2.3 \\
Beam + BPA & 7.8 & 3.8 \\
Beam + BSSB & 3.2 & 1.2 \\
Beam + BSH & 2.9 & nd
\end{tabular}

The errors associated with the above CBE-factors and RBE values were of the order of $\pm 12-15 \%$

(a) $-25 \mu \mathrm{g}{ }^{10} \mathrm{~B} / \mathrm{ml}$ of growth medium

(b) $-38 \mu \mathrm{g} / \mathrm{g}$ average ${ }^{10} \mathrm{~B}$ concentration per tumour

nd - no data 


\section{IMPLICATIONS FOR CLINICAL STUDIES ON THE PETTEN HBII EPITHERMAL BEAM FACILITY}

At the peak physical dose-rate, $22.5 \mathrm{~mm}$ into tissue, $-66 \%$ of the total physical doserate from the epithermal neutron beam is from $\gamma$-rays. However, due to the high RBE of the fast neutrons the biologically equivalent dose from fast neutrons and $\gamma$-rays is similar (Table 6). When $70 \mu \mathrm{g} / \mathrm{g}$ of ${ }^{10} \mathrm{~B}$, from $\mathrm{BSH}$, is present in the blood then the contribution of the ${ }^{10} \mathrm{~B}(\mathrm{~N}, \alpha)^{7} \mathrm{Li}$ reaction to the total biological equivalent dose to the brain would be $53 \%$. A similar effect would be produced by $25 \mu \mathrm{g} / \mathrm{g}$ of ${ }^{10} \mathrm{~B}$ from BPA due to the greater effectiveness of the $\alpha$-particles induced in the presence of this capture agent. The suggestion that $70 \mu \mathrm{g} / \mathrm{g}$ of ${ }^{10} \mathrm{~B}$ from $\mathrm{BSH}$ is required to achieve approximate parity in the biologically effective dose to normal CNS tissue from the ${ }^{10} \mathrm{~B}(\mathrm{n}, \alpha){ }^{7} \mathrm{Li}$ reaction and other components is apparently at odds with figures quoted by others (Gabel, 1993). However, no data was presented to support why $25 \mu \mathrm{g} / \mathrm{g}{ }^{10} \mathrm{~B}$ was felt to be appropriate.

Table 6. Peak physical $(2.25 \mathrm{~cm}$ depth) and biologically equivalent dose contributions from the Petten HBII epithermal beam based on the configuration of Siefert et al. (1992).

Irradiation

Radiation

Dose contribution (\%) component

Physical Biologically
equivalent

\begin{tabular}{llrr}
\hline Beam only & Fast $\mathrm{N}$ & 18 & 44 \\
& $\gamma$-rays & 66 & 38 \\
& ${ }^{14} \mathrm{~N}(\mathrm{n}, \mathrm{p})^{14} \mathrm{C}$ & 10 & 15 \\
& Others & 6 & 3 \\
& Total & 100 & 100
\end{tabular}

Beam + BSH

Fast $\mathrm{N}^{\mathrm{2}}$

22

$\left(70 \mu \mathrm{g} / \mathrm{g}^{10} \mathrm{~B}\right)$

$\gamma$-rays ${ }^{b}$

4

${ }^{14} \mathrm{~N}(\mathrm{n}, \mathrm{p}){ }^{14} \mathrm{C}^{\mathrm{c}}$

13

2

Others

Sub toial

${ }^{10} \mathrm{~B}(\mathrm{n}, \alpha)^{7} \mathrm{Li}^{\mathrm{d}}$

$\frac{1}{20}$

7

Total

$\frac{80}{100}$

$\frac{2}{47}$

$\frac{53}{100}$

$\begin{array}{llcc}\text { Beam + BPA } & \text { Fast } \mathrm{N} & 7 & 19 \\ \left(25 \mu \mathrm{g} / \mathrm{g}{ }^{10} \mathrm{~B}\right) & \gamma \text {-rays } & 28 & 17 \\ & { }^{14} \mathrm{~N}(\mathrm{n}, \mathrm{p}){ }^{14} \mathrm{C} & 4 & 8 \\ & \text { Others } & \frac{2}{41} & \frac{1}{45} \\ & \text { Sub total } & 59 & \frac{55}{100}\end{array}$

${ }^{a-c} \mathrm{RBE}$ value of 4.5, 1.0 and 3.0, respectively (from Gavin et al., 1992)

${ }^{\circledR} \mathrm{CBE}$-factor BSH $0.52,{ }^{\circ} \mathrm{CBE}$-factor BPA 1.52 
When 100 units of biologically effective dose are given to normal healthy tissue the non ${ }^{10} \mathrm{~B}(\mathrm{n}, \alpha)^{7} \mathrm{Li}$ component of this dose will also be delivered and/or be induced in the tumour. However, the ${ }^{10} \mathrm{~B}(\mathrm{n}, \alpha)^{7} \mathrm{Li}$ component of the dose to the tumour will depend on the tumour:blood/normal tissue ratio and the difference in the CBE-factors for tumour vs normal CNS tissue. For BSH (CBE-factor CNS 0.52; tumour 1.2), calculations based on the assumption that $70 \mu \mathrm{g} / \mathrm{g}{ }^{10} \mathrm{~B}$ has been achieved in the blood, with a tumour:blood ratio of 1.0 , would suggest that the biological effective dose to the tumour would be $70 \%$ higher than that to the normal tissue (170 units of dose). Reducing the ${ }^{10} \mathrm{~B}$ level in the blood to $25 \mu \mathrm{g} / \mathrm{g}$ would, based on the same assumptions, only result in an $-40 \%$ increase in the biological effective dose to the tumour. For a comparable dose of ${ }^{10} \mathrm{~B}$ from BPA in blood/normal tissue (CBE-factor CNS 1.52; tumour 3.8), and assuming a tumour:normal tissue ratio of 3.0, similar calculations would produce an -350 unit enhancement in the dose to the tumour relative to the normal CNS tissue. This raises the question, for which no real answer is available, what different in dose between tumour and normal CNS tissue tolerance is required to cure glioblastoma? However, even at doses below that which is conventionally considered to be a safe tolerance dose, from conventional photon therapy, late brain atrophy has been reported (Asai et al., 1989). The present results using rat tumour and normal tissue models indicate that BNCT offers the prospect for a really substantial reduction in radiation dose to normal brain tissue but still retain the potential for local tumour control.

\section{CONCLUSIONS}

In the healthy tissues of the rat, radiobiological parameters have been calculated to aid the safe clinical application of BNCT using the capture agents BSH and BPA. Radiobiological parameters have also been obtained in experimental therapy studies using a rat $9 \mathrm{~L}$-gliosarcoma model. If the radiobiological parameters for this rat gliosarcoma were to be applicable to human glioblastomas and comparable tumour:normal tissue ${ }^{10} \mathrm{~B}$ concentrations were to be obtained in patients, then BPA, as a capture agent, would appear superior to BSH. Pharmacokinetic studies with BPA in patients are needed to help validate this suggestion.

Supported by DOE under Contract DE-AC02-76CH00016. REFERENCES

Asai A, Matsutani M, Kohno T et al. Subacute brain atrophy after radiation therapy for malignant brain tumour. Cancer 1989;63:1962-1974.

Coderre JA, Makar MS, Micca PL et al. Derivation of relative biological effectiveness for the high LET radiation produced during boron neutron capture irradiations of the 9L rat gliosarcoma in vitro and in vivo. Int J Radiat Oncol Biol Phys (in press).

Frankhauser H, Stragliotto G. Zbinden P. Borocaptate sodium (BSH) pharmacokinetics in glioma patients. In: Boron neutron capture therapy. Eds. D Gabel, R Moss (Plenum Press, NY) 1992;155-162. 
Gabel D. Radiobiological considerations concerning the development of compounds for boron neutron capture therapy. Strahlenther Onkol 1993;167:65-70.

Gavin PR, Wheeler FJ, Huiskamp R et al. Large animal model studies of normal tissue tolerance using an epithermal neutron beam and borocaptate sodium. In: Boron neutron capture therapy. Eds. D Gabel, R Moss (Plenum Press, NY) $1992 ; 197-209$

Hatanaka H, Sano K, Yasukochi H, Clinical results of boron neutron capture therapy. In: Progress in neutron capture therapy for cancer. Eds. BJ Allen et al (Plenum Press, NY) 1992;561-568.

Joel DD, Fairchild RG, Laissue JA et al. Boron neutron capture therapy of intracerebral rat gliosarcoma. Proc Natl Acad Sci 1990;87:9808-9812.

Moss RL, Stecher RA, Asmussen F, et al. The Petten BNCT project. In: Progress in neutron capture therapy for cancer. Eds. BJ Allen et al. (Plenum Press, NY) $1992 ;: 7-12$.

Siefert A, Casado J, Moss RL et al. Healthy tissue tolerance studies for BNCT at the high flux reactor in Petten - first results. In: Boron neutron capture therapy. Eds. D Gabel, R Moss (Plenum Press, NY) 1992;179-188.

Slatkin DN. A history of boron neutron capture therapy of brain tumours. Brain 1991;1609-1629.

\section{DISCLAIMER}

\footnotetext{
This report was prepared as an account of work sponsored by an agency of the United States Government. Neither the United States Gnvernment nor any agency thereof, nor any of their employees, makes any warranty, express or implied, or assumes any legal liability or responsibility for the accuracy, completeness, or usefulness of any information, apparatus, product, or process disclosed, or represents that its use would not infringe privately owned rights. Referprocess disclosed, or reprif commercial product, process, or service by trade name, trademark, manufacturer, or otherwise does not necessarily constitute or imply its endorsement, recommanufacturer, or othing by the United States Government or any agency thereof. The views and opinions of authors expressed herein do not necessarily state or reflect those of the United States Government or any agency thereof.
} 

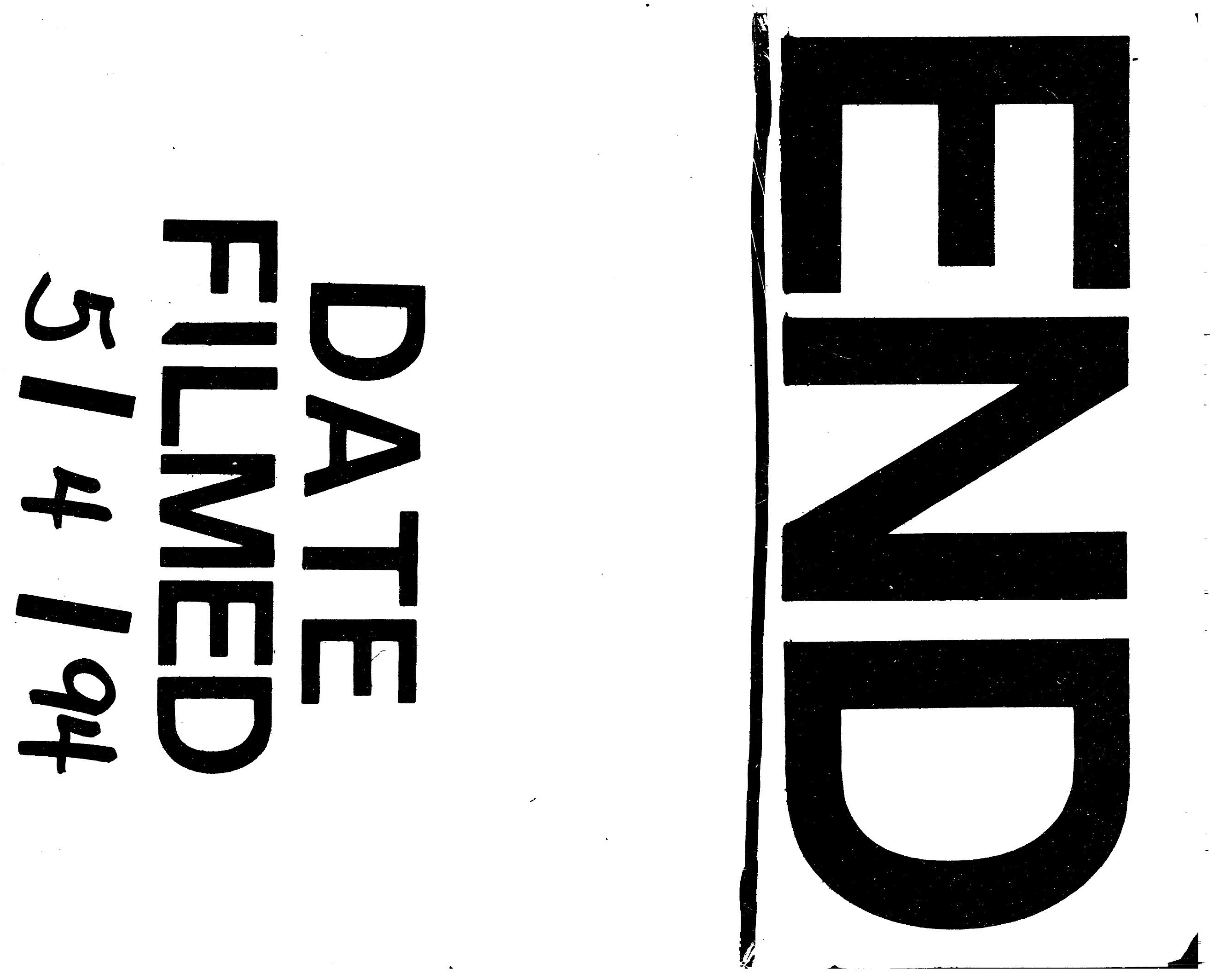
